\title{
Enzymatic and protein differences between infective larvae of Trichostrongylus colubriformis conditioned or not conditioned to hypobiosis
}

\author{
J. VADLEJCH ${ }^{1}$, I. LANGROVÁ ${ }^{1}$, M. BOROVSKÝ ${ }^{1}$, M. SEDMÍKOVÁ ${ }^{2}$, I. JANKOVSKÁ ${ }^{1}$, \\ J. FECHTNER ${ }^{1}$, A. LYTVYNETS ${ }^{3}$
}

\begin{abstract}
${ }^{1}$ Department of Zoology and Fisheries, ${ }^{2}$ Department of Veterinary Sciences, Faculty of Agrobiology, Food and Natural Resources, Czech University of Agriculture, Kamýcká 957, 16521 Prague 6 - Suchdol, Czech Republic, E-mail: vadlejch@af.czu.cz; ${ }^{3}$ Department of Laboratory Animals Breeding and Hygiene, Institute of Physiology, Academy of Sciences of the Czech Republic, Vídeňská 1083, 14220 Prague 4, Czech Republic
\end{abstract}

\begin{abstract}
Summary
The differences in protein and enzymatic profiles of infective larvae $\left(\mathrm{L}_{3}\right)$ of Trichostrongylus colubriformis, both induced and non-induced to hypobiosis, have been evaluated by means of SDS-PAGE and densitometric analysis as well as by semiquantitative micromethod API-ZYM (BioMérieux, France). Quantitative differences were identified in protein levels between the induced and non-induced larvae, where the amount of two polypeptides $(200-220$ $\mathrm{kDa}$ ) decreased in range $32.3-35.4 \%$ and the amount of six polypeptides $(20-28 \mathrm{kDa})$ increased in range $20.0-$ $27.0 \%$ in the samples of induced larvae. In contrast to non-induced larvae, on gelatin-substrate gel in $\mathrm{L}_{3}$ in vitro released (IVR) proteases from larvae conditioned to hypobiosis, zones of proteolysis were observed between 21 and $34 \mathrm{kDa}$.
\end{abstract}

Key words: Trichostrongylus colubriformis; hypobiosis; protein; enzymes; SDS-PAGE; API-ZYM

\section{Introduction}

Parasitic nematode Trichostrongylus colubriformis (Nematoda: Trichostrongylidae) represents an important gastrointestinal parasite infecting ruminants all over the world causing significant production loss in livestock. One of the most important reasons is the presence of a successful mechanism of survival during the external and internal host phase of the nematode life cycle. It is apparent that a variety of trichostrongylid nematodes are able to undergo periods of prolonged but temporary developmental arrest (hypobiosis, inhibition) in their hosts, which represents a useful life cycle adaptation enhancing parasite survival.

It is presumed that the inhibited larvae have low metabolism which enables them to survive for long periods of ti- me. The growth of cessation is almost always facultative because it usually occurs only in a proportion of nematode parasites and under certain circumstances.

It was observed (Armour et al., 1969; Connan 1971; Almeria et al., 1996) that larvae of many trichostrongylids (Trichostrongyloidea) in the Northern Hemisphere enter hypobiosis when they develop into infective stage in autumn but not in summer. It seems evident that the exposure of the larvae on pasture to specific physical stimuli might „preprogramme“ them for future hypobiosis. In recent years it was established that in temperate climates, hypobiosis is related to the advent of cool temperatures and changing photoperiod (Langrová \& Jankovská, 2004).

However, little is known about the biochemical and the physiological conditions underlying the phenomenon of hypobiosis. Ultrastructural studies showed that inhibited Ostertagia ostertagi larvae are metabolically inactive with mitochondria in intestinal cells partly atrophied (Armour \& Bruce, 1974). A study from the Netherlands (Kooyman \& Eysker, 1995) determined whether there are differences in the profiles and/or abundance of proteins associated with inhibited development in Haemonchus contortus by two dimensional gel electrophoresis (2-DGE). The 2-DGE gels showed a large number of resolved polypeptides, of which the majority remained unaltered during the prolonged periods of conditioning. Upon closer examination, it became clear that 7 polypeptides showed differences. Another study was performed in Argentina with $O$. ostertagi $\mathrm{L}_{3}$ using SDS-PAGE and densitometric analysis. Two 75.4 and 70 $\mathrm{kDa}$ protein bands were found which exceeded the control profile by 4.5 and 44 fold, respectively (Dopchiz et al., 2000).

Proteolytic enzymes are very important for a parasitic lifestyle and they are released by many helminths during in 
vitro maintenance (Healer et al., 1991; De Cock et al., 1993; Hadas \& Stankiewicz, 1997). Proteases have got broad importance; some of them are responsible for penetration of host tissue barriers (McKerrow et al., 1990), evasion of host immune response, digestion of host tissue (Tort et al., 1999), retardation of blood coagulation, moulting process (Gamble \& Mansfield, 1996) etc.

In vitro released (IVR) proteases of developmentally arrested infective larvae of nematodes have not been studied to date. The aim of this study is to acquire a preliminary characterisation of proteins and enzymes of infective larvae of T. colubriformis preprogrammed (induced) and nonpreprogrammed (non-induced) to hypobiosis.

\section{Materials and Methods}

Infective larvae of $T$. colubriformis were obtained by culturing the faeces of specific hosts - goats (Capra hircus). These goats represented naturally infected hosts with parasite monoculture. Faeces were cultured at $23^{\circ} \mathrm{C}$ for 10 days. The third stage larvae $\left(\mathrm{L}_{3}\right)$ acquired have been conditioned for 5 weeks to hypobiosis. An electronic fluorescent lamp was used to imitate daylight $(8 \mathrm{~W}, 230 \mathrm{~V}, 50$ $\mathrm{Hz}$ ). Starting with a $12 / 12$ regime, the light period was decreased by 10 minutes each day for 5 weeks. The first group ( $\mathrm{P}$, preprogrammed) was kept in an ice box at $4^{\circ} \mathrm{C}$ (group P4), the second group (P22) at laboratory temperature $\left(22^{\circ} \mathrm{C}\right)$. These conditions evoked hypobiosis in rabbits (Langrová \& Jankovská, 2004). The larvae of the control groups $(\mathrm{C} 4, \mathrm{C} 22)$ were kept in total darkness at $4^{\circ} \mathrm{C}$ and $22^{\circ} \mathrm{C}$ respectively. Another control group was represented by fresh infective larvae $\left(\mathrm{L}_{3}\right.$ acquired after cultivation were immediately used for analysis) without induction of hypobiosis $(\mathrm{C} 0)$.

Control of hypobiosis was effected by inoculation of larvae to six gerbils (Meriones unguiculatus). The first group of gerbils $(n=3)$ was infected by conditoned larvae (P4) and the second group $(n=3)$ with the control group of larvae (C4).

IVR fluid was obtained by a method described by Geldhof et al. (2000). A homogenate of larvae was obtained with a Potter-Eveljhem homogeniser. All the explored larvae were exsheated in $0.2 \%$ sodium hypochlorite before analysis. The methods used for the detection of proteinase activity in polycrylamide gels were modifications of the methods described by Geldhof et al. (2000). As substrates, gelatin, bovine mucine and albumine were incorporated into $10 \%$ SDS-PAGE gel slabs at a final concentration of $1 \mathrm{mg} / \mathrm{ml}$. IVR proteins $(1.4 \mu \mathrm{g} / \mu \mathrm{l})$ were applied to the gel and fractionated under non-reducing conditions. Following electrophoresis first at $90 \mathrm{~V}$ for $30 \mathrm{~min}$ and then at $150 \mathrm{~V}$ gels for 80 min were washed in 3 changes of $2.5 \%$ TritonX-100 over $45 \mathrm{~min}$ to remove the SDS and incubated in appropriate buffer for 20 hours at $37^{\circ} \mathrm{C}$. Zones of proteolysis were vizualized (to obtain clear bands against a blue background) by Coomasie blue staining $(0.1 \%$ Coomasie blue R-250 in $30 \%$ methanol and $10 \%$ acetic acid) followed by destaining in a mixture of $10 \%$ methanol with $10 \%$ acetic acid.

The effect of various inhibitors on enzymatic activity was determined by pre-incubating $\mathrm{L}_{3}$ proteins with inhibitor for 30 minutes at the following final concetrations prior to substrate gel analysis: $1 \mathrm{mM}$ AEBSF for serine proteinases, $5 \mathrm{mM} 1.10$ phenantroline for metallo-proteinases, $10 \mathrm{mM}$ EDTA for metallo-proteinases and $100 \mu \mathrm{M}$ pepstatine for aspartyl proteinases. After electrophoresis gels were sliced, washed in $2.5 \%$ TritonX-100 and gel slices incubated for 20 hours with PBS buffer containing the appropriate inhibitor. Zones of proteolysis were visualized by Coomassie Brilliant Blue R-250. Reduced intensity of banding or total dissapperance in the presence of inhibitors was indicative of proteinase class (Geldhof et al., 2000). The protein profile of infective larvae homogenates was analysed by SDSPAGE under denaturing and reducing conditions. Proteins were stained with Coomasie Brilliant Blue R-250. Area integration analysis was performed using densitometer software.

The IVR fluid and homogenate of these larvae were tested for their enzymatic activity by semiquantitative API-ZYM system (Bio-Mérieux, France) according to the manufacturer's instructions. The third stage larvae $\left(\mathrm{L}_{3}\right)$ acquired that were used had been conditioned to hypobiosis in the same way as described above.

\section{Results}

The rate of inhibition in the conditioned larvae was in the range of $55-100 \%$, in the control group with unconditioned larvae the rate of inhibited larvae was $0-14 \%$.

Differences in the protein profile of $T$. colubriformis were evaluated by means of SDS-PAGE under denaturing and reducing conditions and by means of densitometric analysis. Although no qualitative differences in the protein profile could be detected between induced and non-induced

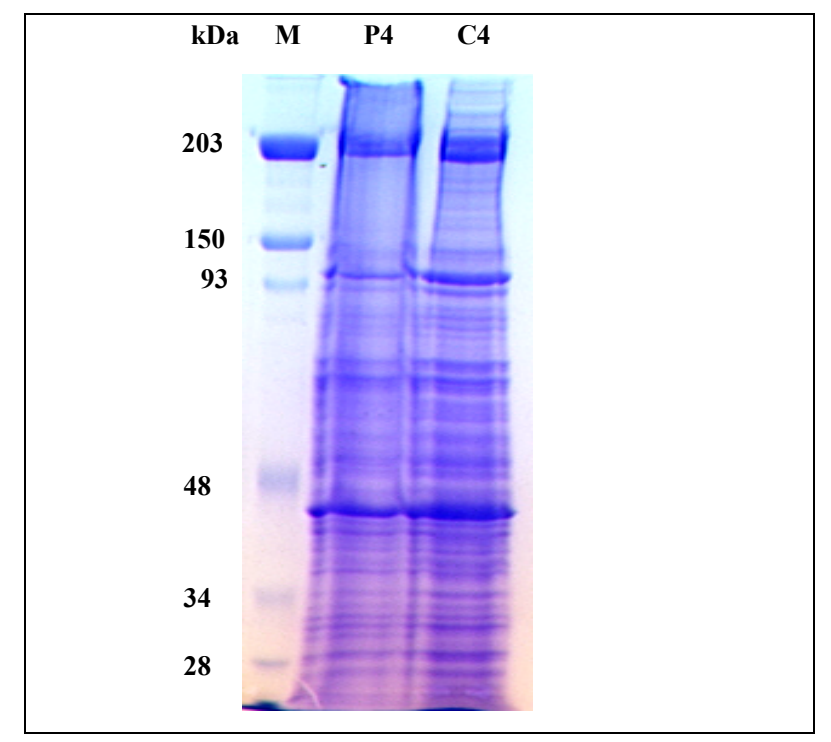

Fig.1. Coomassie Brilliant Blue R250 pattern of a $10 \%$ SDSPAGE of induced (P4) and control (C4) T. colubriformis $\mathrm{L}_{3}$ larval homogenate (MW-SDS-200 kit, Sigma) 


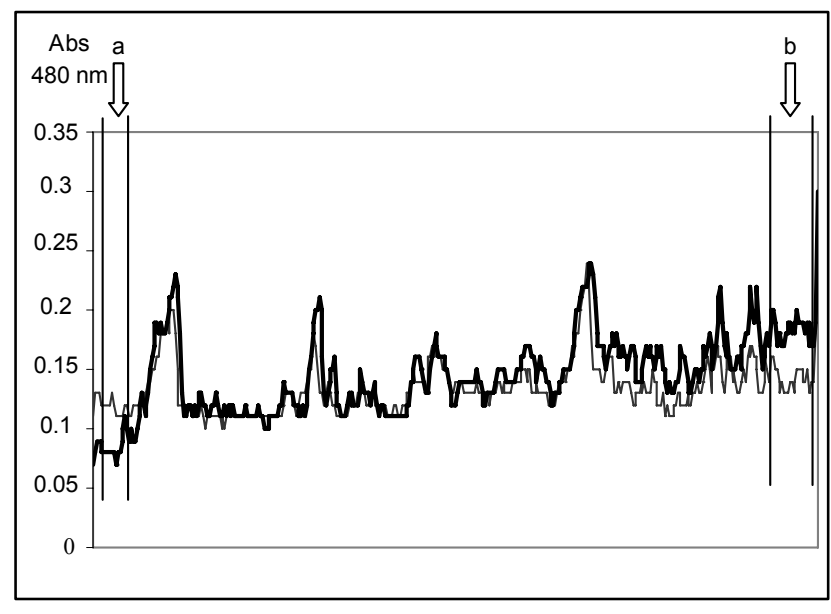

Fig. 2. Densitometry corresponding to the SDS-PAGE. Explanation: (thick line) protein profile of $\mathrm{L}_{3} T$. colubriformis homogenate previously induced to hypobiosis, (thin line) protein profile of $\mathrm{L}_{3} T$. colubriformis homogenate - control population. $\mathrm{a}, \mathrm{b}$ - plases where integration analyses are carried out. (shown Fig. 3 and Fig. 4)

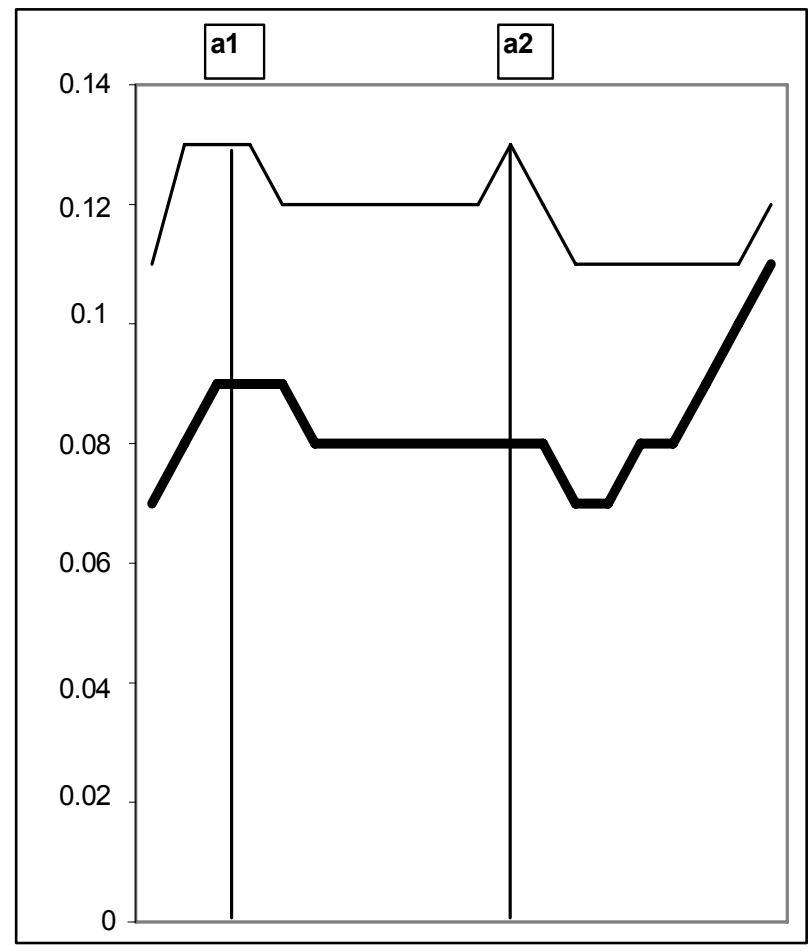

Fig. 3. Integration analysis of band a, comprised between $200-220$ kDa. Explanation: (thick line) protein profile of $\mathrm{L}_{3} T$. colubriformis homogenate previously induced to hypobiosis, (thin line) protein profile of $\mathrm{L}_{3} T$. colubriformis homogenate - control population

larvae (Fig. 1), quantitative differences were identified in the protein levels of the larvae induced to hypobiosis, where the amount of two polypeptides (molecular weight $200-$ $220 \mathrm{kDa}$ ) decreased in range $32.3-35.4 \%$ and the amount of six polypeptides (molecular weight $20-28 \mathrm{kDa}$ ) increased in range $20.0-27.0 \%$ compared to the control sample (Figs 2-4).

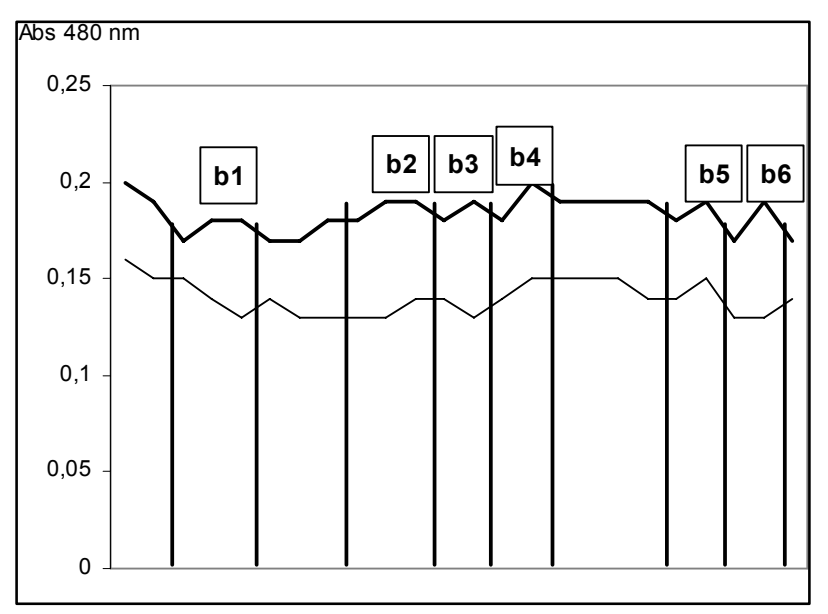

Fig. 4. Integration analysis of band b, comprised between $20-28$ kDa. Explanation: (thick line) protein profile of $\mathrm{L}_{3} T$. colubriformis homogenate previously induced to hypobiosis, (thin line) protein profile of $\mathrm{L}_{3} T$. colubriformis homogenate - control population

Table. 1. Migration and substrate specificity from the stage-specific proteinases released by L3 Trichostrongylus colubriformis ,preprogrammed“ (P) and non-preprogrammed (C) to hypobiosis (- no activity, ++ moderate activity, +++++ strong activity)

\begin{tabular}{lcclllll}
\hline Larvae & \multicolumn{1}{c}{$\begin{array}{c}\text { Migration } \\
(\mathrm{kDa})\end{array}$} & Class & $\mathrm{pH}$ & Gelatin & Mucin Albumin \\
\hline $\mathrm{P} / \mathrm{NP}$ & ${ }^{\circ} \mathrm{C}$ & & & & & & \\
$\mathrm{P}$ & 4 & $21-34$ & metallo & 8.5 & ++ & - & - \\
$\mathrm{P}$ & 22 & $21-34$ & metallo & 8.5 & ++ & ++ & - \\
$\mathrm{C}$ & 4 & 40 & metallo & 8.5 & +++++ & - & - \\
$\mathrm{C}$ & 22 & 40 & metallo & 8.5 & +++++ & - & - \\
$\mathrm{C}$ & 22 & 48 & metallo & 8.5 & - & ++ & - \\
fresh larvae & 205 & metallo & 8.5 & ++ & - & - \\
fresh larvae & 34 & metallo & 8.5 & ++ & - & - \\
\hline
\end{tabular}

The substrate gel electrophoresis under non-reducing conditions was used as the method to identify proteases of $T$. colubriformis infective larvae. IVR fluid of larvae was analysed to determine both molecular weights and the class of enzymes. First of all, degradation of protein substrates was evaluated. Zones of proteolysis on gelatin-substrate gel in $\mathrm{L}_{3}$ IVR from preprogrammed larvae were observed between 21 and $34 \mathrm{kDa}$ with $\mathrm{pH}$ optima 8.5. A strong $40 \mathrm{kDa}$ band was observed in IVR from non-preprogrammed $\mathrm{L}_{3}$, 34 and $200 \mathrm{kDa}$ medium band were noticed in IVR from fresh infective larvae. All these enzymes were inhibited by the metalloproteinase inhibitor EDTA. The weak $48 \mathrm{kDa}$ zone of proteolysis was present on mucine at the same $\mathrm{pH}$ in homogenates from non-preprogrammed $\mathrm{L}_{3}$. This was inhibited by EDTA, too (Table 1).

The presence and activity of enzymes in the samples of $T$. colubriformis infective larvae revealed by the API-ZYM system is displayed in table 2 . All the groups of larvae studied were positive for acid phosphatase (No.11) and 
naphtol-AS-BI-phosphohydrolase (No.12). Some of the samples show wider spectra of enzymes detected. The control groups revealed positive leucyl arylamidase (No.6) and esterase lipase (No.4) reaction. These enzymes were found only in control group not conditioned to hypobiosis.
Quantitative differences were identified in the protein levels of the induced (preprogrammed) larvae, where the protein level of two polypeptides (molecular weight $200-$ $220 \mathrm{kDa})$ decreased and the amount of six polypeptides (molecular weight $20-28 \mathrm{kDa}$ ) increased compared to the

Table 2. Enzymatic profile of larvae detected by API-ZYM system and quantitative expession of released enzyme in nmol.

\begin{tabular}{|c|c|c|c|c|c|c|c|c|c|}
\hline & Enzyme & $\mathrm{F} 4$ & CF4 & $\mathrm{H} 4$ & CH4 & F22 & CF22 & FF & $\mathrm{FH}$ \\
\hline 1. & control & & & & & & & & \\
\hline 2. & phosphatase alcaline & 5 & 40 & 5 & 5 & 5 & 40 & & \\
\hline 3. & esterase (C4) & $0-5$ & & & & & & & \\
\hline 4. & esterase lipase (C8) & $0-5$ & & & 5 & $0-5$ & & & \\
\hline 5. & lipase (C14) & $0-5$ & & & & & & & \\
\hline 6. & leucine arylamidase & $0-5$ & 40 & & & & 40 & & \\
\hline 7. & valine arylamidase & $0-5$ & & & & & & $0-5$ & $0-5$ \\
\hline 8. & cystine arylamidase & $0-5$ & & & & & & & \\
\hline 9. & trypsine & & & & & & & & \\
\hline 10. & $\alpha$-chymotripsine & & & & & & & & \\
\hline 11. & phosphatase acid & 5 & 40 & 5 & 5 & 10 & 40 & & $5-10$ \\
\hline 12. & naphtol-AS-BI-phosphohydrolase & 20 & 40 & 10 & 40 & 30 & 40 & & $5-10$ \\
\hline 13. & $\alpha$-galaktosidase & & & & & & & & \\
\hline 14. & $\beta$-galaktosidase & & & & & & & & \\
\hline 15. & $\beta$-glucuronidase & & & & & & & & $0-5$ \\
\hline 16. & $\alpha-$ glucosidase & & & & & & & & \\
\hline 17. & $\beta$-glucosidase & & & & & & & & \\
\hline 18. & $N$-acetyl- $\beta$ glucosamidase & & & & & & & & \\
\hline 19. & $\alpha$ mannosidase & & & & & & & & \\
\hline 20. & $\alpha$ fucosidase & & & & & & & & \\
\hline
\end{tabular}

F4 - IVR fluid of larvae kept under decreasing photoperiod and at $4{ }^{\circ} \mathrm{C} ; \mathrm{H} 4$ - homogenate of larvae kept under decreasing photoperiod and at $4{ }^{\circ} \mathrm{C}$; F22 - IVR fluid of larvae kept in the dark and under decreasing photoperiod and at $22^{\circ} \mathrm{C}$; CF4, CH4 and CF22 - IVR fluid (F) or homogenate (H) of larvae kept in the dark and at the same temperature as corresponding groups (control groups); FF - IVR fluid of fresh larvae; FH - homogenate of fresh larvae; Homogenates of larvae induced at $22^{\circ} \mathrm{C}(\mathrm{H} 22)$ and control larvae $(\mathrm{CH} 22)$ were not included to the experiment by reason of high larval mortality

\section{Discussion}

Little is known of the proteinous state underlying the phenomenon of hypobiosis. As far as we know, only a comparison of changes in proteins following conditioning for inhibition in both inhibited and non-inhibited populations of Haemonchus contortus and Ostertagia ostertagi was published before (Kooyman \& Eysker, 1995; Dopchiz et al., 2000).

Generally, trichostrongylids are inhibited as early as $\mathrm{L}_{4}$ but Trichostrongylus spp. are inhibited as $\mathrm{L}_{3}$. The effects of seasonal factors and host resistance for the induction of inhibited development have been recognised in T. colubriformis in rabbits (Jankovská et al., 2003 a,b; Langrová \& Jankovská, 2004). These studies did not, however, investigate the biochemical basis of hypobiosis. Our report provides a first preliminary description of differences in the protein and enzymatic activity of infective larvae of $T$. colubriformis in small ruminants preprogrammed and nonpreprogrammed to hypobiosis. control sample.

In order to determine whether there are differences in the enzymatic profiles associated with inhibited development, we have examined both induced and non-induced to hypobiosis infective larvae by a semi-quantitative method (APIZYM, Bio-Mérieux, France) and substrate gel analysis under non-reducing conditions. SDS-PAGE has detected proteinases able to degrade gelatin and mucin substrates. At alkalic $\mathrm{pH}$, some proteinases have been present in IVR products of preprogrammed larvae $(21-34 \mathrm{kDa})$, others appeared only in IVR control, non-preprogrammed larvae $(40 \mathrm{kDa})$ and fresh larvae $(200 \mathrm{kDa})$. The results of SDSPAGE electrophoresis, both under reducing and non-reducing conditions, have shown that at least the $21-28$ $\mathrm{kDa}$ proteins (proteases) may have been related to conditioning for arrested development of $T$. colubriformis.

We documented here by means of the API-ZYM method differences in released enzymes with metabolic importance 
(phosphatase alcaline, phosphatase acid and naphtol-ASBI-phosphohydrolase). The results are in concordance with a presumed low metabolism of arrested larvae (Eysker, 1993). We suppose that both decreasing photoperiod and low temperatures induced the changes in the activity of these enzymes.

The present work has demonstrated changes in protein level corresponding with biological changes induced by conditions causing T. colubriformis hypobiosis. In accordance with the results of Kooyman and Eysker (1995) and Dopchiz et al. (2000), we have proved that no major changes occur at the protein level upon induction of arrested development. The observed differences in their abundance represent a first step in understanding the biochemical basis of arrested development in a nematode parasite, T. colubriformis. Similar studies with an ovine abomasal nematode, Teladorsagia circumcincta are planned. The combination of protein analysis, through peptide sequencing and biochemical characterisation, interfaced with gene sequenece analysis can give better results to understading the phenomenon of hypobiosis.

\section{Acknowledgements}

This study was supported by the Research Project of the Faculty of Agrobiology, Food and Natural Resources, Czech University of Agriculture in Prague, No. MSM 6046070901. Experiments comply with current laws of the country in which they were performed.

\section{References}

Almería, S., Llorente, M. M., Uriarte, J. (1996): Monthly fluctuations of worm burdens and hypobiosis of gastrointestinal nematodes of calves in extensive management systems in the Pyrenees (Spain). Vet. Parasitol., 67: $225-236$

Armour, J., Jennings, F. W., Urguhart, G. M. (1969): Inhibition of Ostertagia ostertagi at the early fourth stage. The influence of environment on host or parasite. Res. Vet. Sci., 10: $238-244$

ARMOUR, J., BRUCE, R. G. (1974): Inhibited development in Ostertagia ostertagi infections - a diapause phenomenon in a nematode. Parasitology, 69: 161-174

CONNAN, R. M. (1971): The Seasonal Incidence of Inhibition of Development in Haemonchus contortus. Res. Vet. Sci., 12: $272-274$

De Cock, H., Knox, D. P., Claerebout, E. De GraAf, D. C. (1993): Partial characterisation of proteolytic enzymes in different developmental stages of Ostertagia ostertagi. J. Helminthol., 67: $271-278$

Dopchiz, M. C., PARMA, A. E., Fiel, C. A. (2000): Hypobiosis induction alters the protein profile of Ostertagia ostertagi (Nematoda: Trichostrongylidae), Folia Parasitol., 47: 135 - 140

EYSKER, M. (1993): The role of inhibited development in the epidemiology of Ostertagia infections, Vet. Parasitol., 46: $259-269$

GAMBLE, H. R., MANSFIELD, L. S. (1996): Characterisation of excretory - secretory products from larval stages of Haemonchus contortus. Vet. Parasitol., 62: 291 - 305

Geldhof, P., Claerebout, E., Knox, D. P., Agneessens, J., VERCRUYSSE, J. (2000): Proteinases released in vitro by the parasitic stages of the bovinne abomasal nematode $O s$ tertagia ostertagi. Parasitology, 121: $639-647$

HADAS, E., STANKIEWICZ, M. (1997): Proteolytic enzymes of infective larvae and adults of Trichostrongylus colubriformis and Haemonchus contortus. Parasitol. Res., 83: $47-51$

Healer, J., Ashall, F., Maizels, R. M. (1991): Characterisation of proteolytic enzymes from larval and adult Nippostrongylus brasiliensis. Parasitology, 103: 305 - 314

JANKOVSKÁ, I., LANGROVÁ, I., VADLEJCH, J. (2003a): Arrested development of Trichostrongylus colubriformis in experimentally infected rabbits. Effect of acquired resistance, single, multiple doses and size of doses on rise of hypobiosis. Scientia Agriculturae Bohemica, 34: 58 - 62

JANKOVSKÁ, I., LANGROVÁ, I., FuČÍKOVÁ, A., BOROVSKÝ, M. (2003b): Effect of parasitic nematodes Trichostrongylus colubriformis on haematological parameters of model host (Oryctolagus cuniculus f. domestica). Scientia Agriculturae Bohemica, 34: $94-98$

KoOYMAn, F. N. J., EYSKER, M. (1995): Analysis of proteins related to conditions for arrested development and differentiation in Haemonchus contortus by two - dimmensional gel electrophoresis. Int. J. Parasitol., 25: $561-568$ LANGROVÁ, I., JANKOVSKÁ, I. (2004): Arrested development of Trichostrongylus colubriformis in experimentally infected rabbits. Effect of decreasing photoperiod, low temperature and desiccation. Helminthologia, 41: $85-90$ McKerrow, J. H., Brindley, P., Brown, M., Gam, A., Staunton, C., Neva, A. F. (1990): Strongyloides stercoralis: Identification of a Protease that facilitates Penetration of Skin by the Infective Larva. Exp. Parasitol., 70: $134-143$

Tort, J., Brindley, P. J., Knox, D., Wolfe, K. H., DALton, J. P. (1999): Proteinases and associated genes of parasitic helminths. Adv. Parasit., 43: $161-166$ 